greater mobility of scientists or greater cross-fertilisation of ideas with industry, involves judgement of human behaviour and a bit of applied psychology. Psychology, however, is not one of the hard sciences, says Aigrain, who was initially trained as a solid state physicist. But since he became science minister one year ago it has assumed a greater role in his working life.

Aigrain came to the post after a varied career in both science and administration. As a young physicist he was appointed by General de Gaulle in 1958 to the newly created comité de sages (CCRST) - de Gaulle had wanted some young blood on the committee - and later through earlier connections as a naval officer, he was appointed head of an advisory committee concerned with defence research.

After a spell with responsibility for higher education and a five year term as head of the DGRST (1968-73), he moved into private industry to become general technical manager of Thomson. "I had planned that the rest of my active life would be spent as general technical manager of an industrial company. I have never been involved in active politics, so it was a very great surprise to me when the Prime Minister, Raymond Barre, asked me to enter the government in April 1978.",

Pierre Aigrain is one of a handful of
French ministers who have never run for election. Another is André Giraud, the industry minister, under whose department science and technology officially come. The job of the science minister, however, is unique in the French government.

"I operate by delegation from the Prime Minister on inter-ministerial matters. My work mostly involves coordination, strategy, planning and budgeting of civilian $R \& D$ in all ministerial departments. This is a rather different job from that of a minister who has to run a department. What I have to do is convince my colleagues or the Prime Minister of what should be done in matters of science and technology. It's a rather special sort of job." The DGRST is directly under his responsibility. "DGRST is really my operating cabinet and my means of action."

Determining the science budget, and how it should be spent, is Pierre Aigrain's major task. France currently spends about $1.8 \%$ of its gross national product on R\&D. Ten years ago, the figure used to be $2.1 \%$; 20 years ago it was well below $1 \%$. In spite of the decrease in this percentage over the past ten years, the volume of research has increased very slightly because of the modest growth in GNP.

On the whole, M. Aigrain believes that the French government is sympathetic to

\section{What the report says about French science}

TEN thousand people, of whom 4,500 are qualified scientists, are employed in fundamental physics research in France. The budget for paying their salaries and buying equipment for their work is about $1.7 \mathrm{~m} \mathrm{FF}$ per year. A further 3,500 researchers are employed in physics for engineering.

The DGRST study found French fundamental physics rather healthy, especially in the fields of high energy physics (where France has a reputation for building bubble chambers), nuclear physics, thermonuclear fusion and solid state physics. (The latter is an example of a fundamental branch of research which has good links with industry.) Gravitation, cosmic rays and molecular physics are weak, however.

In applied physics, says the report, the results of research in optics and fluid mechanics are finding their way into industry, but those in solid mechanics and materials sciences are not. The quality of research, for example, in materials sciences is good, but it is unevenly distributed amongst sub-fields and is too academic to be well tuned to the needs of industry. Chemical research done in universities and government laboratories, however, has close links with the chemical industry, but there is need for even greater collaboration. In quantum chemistry, radiochemistry, nuclear chemistry and catalysis (with the exception of catalysis by enzymes) collaboration is good; but it is poor in electrochemistry and chemical engineering. Much of the research is very dispersed and there is a need for some regrouping.

About 4,500 full-time and 6,000 parttime scientists are employed in life sciences research. Areas of which France is particularly proud include cellular and molecular biology, endocrinology, applied immunology and and reproduction and development. Over the past seven years, the programme in the latter has led to a reduction in perinatal death from 23.4 to 16 per thousand. Bacteriology and human nutrition, however, are very weak and neurobiology is currently being 'rejuvenated'.

In energy research, a field with important social and economic implications, the report says that France is doing well in nuclear energy and solar power. It is going ahead in 1982 with plans to start building light water reactors under licence from Westinghouse and with the construction of its demonstration commercial fast breeder reactor, Superphenix. In renewable energy research, it is putting most of its efforts on solar energy and in the long term, thermonuclear fusion. Research on fossil fuels is strong when it comes to prospecting for off-shore for oil (France is well renowned for off-shore technology weak when it comes to coal research. because of its efforts in this area) but the needs of science and technology. His main problem with parliament, however, is to explain "why, with the budget we have, we should put money on this and that and not necessarily on some of the ideas which are in the news - which may not be the best, or which anyway, cannot be efficient unless we also maintain a sufficient amount of basic research.",

He agrees that parliament could be much better informed. A group of MPs, known as Intergroup, used to meet regularly to discuss science policy issues, but with the pressure of seemingly more urgent commitments, this has lapsed and there is now no equivalent of the UK select committee structure wherebvy MPs can gather the opinion of scientists at the grass roots. Something along these lines would be "very useful", however. Scientists "have a duty to try to explain to politicians what the problems of science are, not in party political, but in science policy terms: down to earth terms".

For one reason or another, France has missed out on many of the debates around science policy issues which have aroused public interest in recent years in other industralised countries. In the case of nuclear energy, Pierre Aigrain thinks that the French people recognise that their country, having very few energy resources of its own, is in a particularly difficult position. "There may be many Frenchmen who don't like nuclear energy", he says, "but there are few who doubt that it is necessary',.

In the case of genetic engineering, the French public recognised early on, the confusion surrounding the debate in other countries, where concern had centred on the possibility that "some experimentation could be dangerous for the people doing it or the immediate surroundings" and "the vague fear" that genetic engineering could lead to "ethically unacceptable" experiments. "In France I think it was clear from the start that these were two different problems. The problems of the dangers could obviously be handled provided that scientists took the right precautions. People are, I think rightly satisfied that we can handle this problem because we have been handling a much more difficult one for tens of years," - namely the production of large quantities of vaccine from live virus.

About health and safety generally, and concern over carcinogens and toxic substances, M Aigrain says that there are worries in France, but that "up until now, Frenchmen have been a little more rational and a little less emotional. We in France have a big drawback. We tend to have too much of an analytical mind - we are too rationalistic, too Cartesian. In research this is not necessarily an advantage because, in order to be creative, researchers have to be a lot more pragmatic. But it does have the advantage that even the average Frenchman can realise relatively easily that a debate is created on a non-logical basis". 